\title{
Everything in its Right Place?
}

\section{The Macron Moment and the Complexities of Restituting Africa's Cultural Heritage}

Abstract: In November 2017, French President Emmanuel Macron pledged to return African cultural heritage stored in French public collections to their original owners. One year later a working group around Senegalese economist Felwine Sarr and French art historian Bénédicte Savoy produced a widely received report proposing how this process of restitution could be put in practice. Both speech and so-called restitution report provided a vital stimulus to the ongoing debates across European countries about the appropriate handling of objects and artefacts acquired in territories under European colonial domination. This essay situates the current Macron moment within the longer international controversies on colonial restitution that had already gained momentum in the late 1970s. It queries the cultural diplomacy behind Macron's speech and addresses both the Afrotopian potential that informs much of the optimism of the report and the tensions between the righting of historical injustices and the historical complexities of colonialism that arise from the report's privileging of restitution over provenance research. Charting the reverberations of the report across the European world museum world, the essay analyses how the report has shifted the moral parameters of the debate about colonial objects in Germany and discusses how the aims of restitution and in-depth provenance research could possibly be reconciled.

"Starting today, and within the next five years, I want to see the conditions put
in place so as to allow for the temporary or definitive restitution of African cul-
tural heritage to Africa." With these words French President Emmanuel Macron
pledged to make restitution a priority of his country's cultural politics in front of
an audience of some 800 students at the University of Ouagadougou, the capital
of Burkina Faso, in November 2017. Ever since this announcement, the self-im-
posed five-year-countdown has been ticking. As a first step towards turning the
promise of restitution into practice, the French President commissioned a work-
ing group around Senegalese economist Felwine Sarr and French art historian
Bénédicte Savoy to compile a report how to implement this pledge. One year
after Macron's announcement, in November 2018, the two scholars published

Ә Open Access. (C) 2019 Bernhard Gissibl, published by De Gruyter. (cc) BY-NC-ND This work is licensed under a Creative Commons Attribution-NonCommercial-NoDerivatives 4.0 International License.

https://doi.org/10.1515/9783110635942-010 
their report on "The Restitution of African Cultural Heritage". ${ }^{1}$ Even more than Macron's speech, the report he commissioned provided a vital stimulus to ongoing debates across European countries about the appropriate handling of objects and artefacts acquired in territories under European colonial domination. The following essay charts this debate triggered by the French President, first by situating the current "Macron Moment" within the longer international controversies on colonial restitution that had already gained momentum in the late 1970s. Then, it discusses Macron's speech as an attempt at personal distinctiveness within the inherited politics of Françafrique, using cultural politics as a symbol of change within an African policy that is otherwise marked by stark continuities as well as competition with China. In a third step, the Sarr/Savoy-report is analysed as a political document written by scholars trying to hold the President accountable to his pledge. Afterwards, the essay addresses the varying reverberations the report has had in the world of world museums across Europe, finally focussing on the enormous and polarizing influence it has exerted in Germany. Here, it pitted the project of restitution against the investigation of provenances that was already under way in many museums, raising the question of how these projects could possibly be reconciled.

\section{Restitution for Authenticity - Forward to the 1970 s}

The restitution report by Felwine Sarr and Bénédicte Savoy has fanned and instilled a new urgency into a debate over decolonization, displaced heritage, and cultural sovereignty that had been lingering for about half a century. If not longer, given the fact that, at least since 1935, each Oba of Benin has demanded the restitution of at least some of the artefacts a notorious British punitive expedition had looted from the West African kingdom in $1897 .^{2}$ Despite the obvious, yet complicated case of the Benin objects, it was not until the early 1970 s that a broader international debate emerged about the return,

1 Felwine Sarr and Bénédicte Savoy: The Restitution of African Cultural Heritage. Towards a New Relational Ethics. November 2018, URL: http://restitutionreport2018.com/sarr_savoy_en. pdf (last accessed 30 May 2019).

2 See e.g. Audrey Peraldi: Oba Akuenza II's Restitution Requests, in: Kunst \& Kontext 2017/1, 23-33; Barbara Plankensteiner: The Benin Treasures. Difficult Legacy and Contested Heritage, in: Brigitta Häuser-Schäublin and Lyndel V. Prott (eds.): Cultural Property and Contested Ownership. The Trafficking of Artefacts and the Quest for Restitution. London 2016, 133-155. 
repatriation or restitution of objects and artefacts displaced under colonial rule. At that time, African leaders and intellectuals realized that decolonization was incomplete if restricted to political independence, having to encompass elements of economic and cultural sovereignty, too. It was the president of the then Republic of Zaïre, Mobutu Sese Seko, who drew the world's attention to the fact that the majority of his country's artistic patrimony was located outside Africa due to "systematic pillage" conducted under European colonialism. Therefore, "the rich countries, who possess the artworks of the poor countries", should at least "return part of them". ${ }^{3}$ Understanding restitution as a core element of his decolonial cultural politics of authenticité, Mobutu used the United Nations and its cultural organization UNESCO as stages for claims-making, especially in order to gain leverage in bilateral debates with Belgium as the former colonial power. ${ }^{4}$ His initiative, backed by other African states, sections of the Third World movement and the occasional museum director or curator within Western European societies, resulted, in December 1973, in UN-resolution 3187, which directly referred to the "restitution of works of art to countries victims of expropriation". The issue was advanced by the first African Director-General of UNESCO, the Senegalese Amadou-Mahtar M'Bow, who pushed the "return of cultural assets to their countries of origin" as a "legitimate claim" within the framework of his organisation. ${ }^{5}$ In October 1978, UNESCO installed the Intergovernmental Committee

3 Mobutu Sese Seko addressing the Congress of the International Association of Art Critics in Kinshasa in September 1973, quoted in Sarah van Beurden: Restitution or Cooperation? Competing Visions of Post-Colonial Cultural Development in Africa (Global Cooperation Research Papers 12). Duisburg: Käte Hamburger Kolleg/Centre for Global Cooperation Research (KHK / GCR21) 14 (2015) (doi: 10.14282/2198-0411-GCRP-12). For the broader context, see van Beurden: Authentically African. Arts and the Transnational Politics of Congolese Culture. Athens/OH 2015.

4 Sarah van Beurden: The Art of (Re)possession. Heritage and the Cultural Politics of Congo's Decolonization, in: Journal of African History 56 (2015), 143-164. On the broader context of 1970s international debates about authenticity, see Andrea Rehling and Johannes Paulmann: Historische Authentizität jenseits von “Original” und "Fälschung”. Ästhetische Wahrnehmung gespeicherte Erfahrung - gegenwärtige Performanz, in: Martin Sabrow and Achim Saupe (eds.): Historische Authentizität. Göttingen 2016, 91-125, esp. 121-123; Winfried Speitkamp: “Authentizität” und Nation. Kollektivsymbolik und Geschichtspolitik in postkolonialen afrikanischen Staaten, in: Klaudia Knabel, Dietmar Rieger and Stephanie Wodianka (eds.): Nationale Mythen - kollektive Symbole. Funktionen, Konstruktionen und Medien der Erinnerung. Göttingen 2005, 225-243.

5 An Appeal by Mr. Amadou-Mahtar M'Bow, Director-General of UNESCO: A Plea for the Return of an Irreplaceable Cultural Heritage to Those Who Created It, in: The Unesco Courier 31, July 1978, 4. 
for Promoting the Return of Cultural Property to its Countries of Origin or its Restitution in Case of Illicit Appropriation with the task to mediate and facilitate bilateral interstate negotiations for the return of specific objects. By 1979, sympathetic experts within the International Council of Museums (ICOM) regarded "the reassembly of dispersed heritage through restitution or return of objects which are of major importance for the cultural identity and history of countries having been deprived thereof" as an "ethical principle recognized and affirmed by the major international organizations". 6

This optimistic assessment may have been true for organizations like UNESCO and ICOM, but not necessarily for all of their members. As it turned out, principled recognition did not pertain to Western governments and museums. It still awaits in-depth and source-based historical investigation into how exactly, in the interplay of various levels from international organizations down to individual museums, the impetus for restitution was refused, deferred, watered down and deflected into political deals or culture- and museum-related development cooperation. ${ }^{7}$ Already the 1973 UN-resolution went no further than registering a "special obligation" of former colonial powers in this matter. ${ }^{8}$ The former colonial powers, including France and Western Germany, were successful in defending the non-retroactive character of any international convention that related to displaced cultural heritage. They managed to transform a terminology of legitimate and rights-based restitution into a language of voluntary return and cooperation; victims of expropriation became communities of origin. The repatriation of artefacts was depoliticized and integrated into broader policies of development cooperation in the field of culture. The Intergovernmental Committee faced a mission as cumbersome and complicated as its name. Its importance lies not with the respectable number of objects it managed to return after often yearslong negotiations, but with the fact that it existed at all. Like the UN system in general, ${ }^{9}$ the Committee has provided a forum in which formerly colonized

\footnotetext{
6 Herbert Ganslmayr et al.: Study on the Principles, Conditions and Means for the Restitution or Return of Cultural Property in View of Reconstituting Dispersed Heritages, in: Museum International 31, 1 (1979), 62-66, here 66.

7 Bénédicte Savoy: Die verdrängte Debatte, in: Süddeutsche Zeitung, 3 March 2019. A revealing controversy between German museum directors has recently been reconstructed by Anna Valeska Strugalla: Ein Ding der Unmöglichkeit, in: taz, 11/12 May 2019, URL: http://www.taz.de/ Rueckgabe-von-geraubter-Kunst/!5591215/ (30 May 2019).

8 For a survey, see Thomas Fitschen: 30 Jahre Rückführung von Kulturgut. Wie der Generalversammlung ihr Gegenstand abhanden kam, in: Vereinte Nationen 2004/2, 46-51.

9 See the latest resolution A/RES/73/130 on the Return or restitution of cultural property to the countries of origin adopted by the UN-General Assembly on 13 December 2018, URL: https://www.un.org/en/ga/search/view_doc.asp?symbol=A/RES/73/130 (30 May 2019).
} 
countries could articulate their claims and create awareness for the problem. But generally, the international law regarding cultural heritage has remained underdeveloped, especially when compared to booming policy fields like the environment or human rights. "There is no denying”, Australian legal scholar Ana Filipa Vrdoljak concluded in 2008, "that there had been a sustained resistance in certain quarters to the formulation and implementation of an international legal framework in the cultural heritage field, especially in respect to the removal and return of cultural objects." ${ }^{\text {"10 }}$ Sarr and Savoy state the same in more scathing terms: There has been "no progressive movement [towards restitution] for the past 40 years". ${ }^{11}$

\section{The Macron Moment}

One must bear this long prehistory in mind in order to understand the extraordinary hope and promise associated with the Macron moment. For the first time in the long history of claims and negotiations between global North and global South, the highest representative of a former colonial power has called his country's colonial rule a crime against humanity and proactively pledged restitution. Commentators across the political spectrum were astonished by the "brilliant recklessness" of Macron's initiative and the report it produced, ${ }^{12}$ which was likened to taking a wrecking ball to the quaint and tranquil world of ethnographic and anthropological museology. ${ }^{13}$ Sceptical and critical observers shiver at this recklessness, fearing for the dilapidation of Europe's museum collections and their universal character, and warning against selling the objects as indulgences for the wrongs of colonialism. ${ }^{14}$ Activists for restitution, on the other hand, tend

10 Ana Filipa Vrdoljak: History and Evolution of International Cultural Heritage Law. Through the Question of the Removal and Return of Cultural Objects. Seoul 2008, 4-5.

11 Sarr/Savoy: Restitution of African Cultural Heritage, 21.

12 Peer Teuwsen: Experten in Frankreich empfehlen die sofortige Restitution zahlreicher Kulturgüter aus der Kolonialzeit (21 November 2018), in: NZZ, URL: https://www.nzz.ch/feuille ton/in-frankreich-fragt-man-bang-werden-jetzt-unsere-museen-geleert-ld.1438527 (30 May 2019).

13 Alexander Herman: Legal challenges remain for restituting African artefacts from French museums (28 November 2018), in: The Art Newspaper, URL: https://www.theartnewspaper. com/comment/french-report-calls-for-massive-restitution-of-african-artefacts-while-macronpromises-return-of-26-items-to-benin (30 May 2019).

14 See e.g. Bahners: Französisches Ausleerungsgeschäft; Hermann Parzinger: Zeitenwende oder Ablasshandel?, in: Frankfurter Allgemeine Zeitung 29 November 2018, URL: https://www.faz.net/ aktuell/feuilleton/debatten/wie-sollte-man-mit-kolonialen-kulturguetern-umgehen-15914615-p2. html?printPagedArticle=true\#pageIndex_1 (30 May 2019); Erhard Schüttpelz: Everything must go. Looting the Museum as Compensation for Looting the World. Raubkunstforschung als angewandte 
to regard Macron as the long-awaited Alexander determined to untie the Gordian knot of displaced cultural heritage. Just a few days after the speech, Ghanaian columnist Kwame Opoku, who has commented on issues of cultural restitution for the online media portal Modern Ghana in more than two hundred articles since $2008,{ }^{15}$ hailed Macron's declaration as "historical", for it set a new moral yardstick for restitution. He enthusiastically announced the advent of a "post Ouagadougou period" in which the universal claim of Western museums was on the defensive. ${ }^{16}$ In another article, Opoku invoked "our African gods and ancestors to bless Bénédicte Savoy, Felwine Sarr and their team” for restoring "part of the self-respect and dignity" that had been lost as a consequence of colonial conquest and rule. ${ }^{17}$ In a similar vein, postcolonial activist groups and advocates of restitution in Europe discerned a sea change and a radical new beginning in Euro-African relations effected by the report. ${ }^{18}$ However, the long history of deferred restitution should caution against too great expectations regarding swift or wide-ranging action. Back in 1979, the ICOM working group was equally convinced that the restitution of objects with core cultural significance for their communities of origin would "soon become an element of jus cogens of international relations". ${ }^{19}$ But international law, itself a product of imperial expansion and in significant ways developed to enable and legitimize it, ${ }^{20}$ did not develop as expected. In order to enact restitution as wholesale as

Wissenschaft, URL: https://boasblogs.org/humboldt/everything-must-go-looting-the-museum-ascompensation-for-looting-the-world/ (27 July 2019).

15 See https://www.modernghana.com/author/KwameOpoku (30 May 2019).

16 Kwame Opoku: Humboldt Forum And Selective Amnesia: Research Instead Of Restitution Of African Artefacts (21 December 2017), URL: https://www.modernghana.com/news/824314/ humboldt-forum-and-selective-amnesia-research-instead-of-re.html (30 May 2019).

17 Kwame Opoku: Further Comments On Sarr-Savoy Report On Restitution (31 January 2019), in: Modern Ghana, URL: https://www.modernghana.com/news/912541/further-comments-onsarr-savoy-report-on-restitution.html (30 May 2019).

18 See, for example, Jürgen Zimmerer's interview with Dieter Kassel: Ein Vorschlag von 'globaler Tragweite', in: Deutschlandfunk Kultur, 22 November 2018, URL: https://www.deutschland funkkultur.de/koloniale-raubkunst-ein-vorschlag-von-globaler-tragweite.1008.de.html?dram:arti cle_id=433866 (30 May 2019). Cf. already the open letter of several postcolonial activist groups to Chancellor Angela Merkel concerning the restitution of cultural objects and human remains to Africa, 18 December 2017, URL: http://www.no-humboldt21.de/offener-brief-zur-rueckgabevon-afrikanischen-kulturobjekten-und-menschlichen-gebeinen/ (30 May 2019).

19 Herbert Ganslmayr et al.: Study on the principles, conditions and means for the restitution or return of cultural property in view of reconstituting dispersed heritages, in: Museum International 31, 1 (1979), 62-66, here 66.

20 See e.g. Anthony Anghie: Imperialism, Sovereignty, and the Making of International Law. Cambridge 2012; further the legal scholarship conducted under the label of Third World 
recommended by their report, Sarr and Savoy propose to use bilateral agreements as a lever to facilitate an exception to the principle of the inalienability of cultural objects in public ownership. If Macron followed this proposal, he would, if not abandon, definitely undermine the legal tradition of the inalienability of public collections that dates back as far as the Edict of Moulins in 1566. ${ }^{21}$ Given the historical reach of the French Empire into the Middle East, Asia and Oceania, this would have ramifications far beyond the restitution of African cultural heritage currently under discussion.

So far, the radical rhetoric of the report still awaits corresponding action. But the radical potential of Macron's pledge, the expectations it raised and the transnational debates it fanned, created a discursive situation in which the French president's motives behind his motion have hardly been questioned. After all, the opportunity of the Macron moment needed to be seized, not interrogated for the purity of his intentions. Yet neither the verbal pledge nor the restitution it promised have happened in a political vacuum. Macron's remarks on the restitution of Africa's cultural heritage were but a few sentences towards the end of a verbose speech that lasted about two hours. It was Macron's first speech on the African continent, and as such, it was a signal to both the millions of citizens with electoral rights and family ties to the African colonies, and to the citizens of Francophone Africa. According to political scientist Oumar Ba, first African speeches by French Presidents habitually contained an obituary of the Françafrique as we knew it, the promise of a new departure for a common future with Africans on African terms, a proud comment on shared Francophonie, and a list of present challenges in which France will aid Africans. ${ }^{22}$ Among the challenges enumerated were terrorism, climate change, overpopulation, urbanization and migration. The speech also did not fail on the usual pledge regarding the percentage of the gross national income to be dedicated to development aid. (This time it was 0,55\%, back in 1995 Jacques Chirac still promised $0,7 \%$.) But these were standard issues. The pledge to restitution was Macron's personal endowment, a markedly different policy than all his predecessors in office pursued. Indeed, if there was one word that stood out throughout his speech, it was "generation". Macron used the term twenty

Approaches to International Law (TWAIL): Makau W. Matua: What is Twail?, in: American Society of International Law, Proceedings of the 94th Annual Meeting 2000, 31-39.

21 Marc Weber: Unveräußerliches Kulturgut im nationalen und internationalen Rechtsverkehr. Berlin 2002.

22 Oumar Ba: Should Africans care for Emmanuel Macron's “African speech” in Ouagadougou? (29 Nov 2017), URL: https://africasacountry.com/2017/11/should-africans-care-for-emmanuel-mac rons-africa-speech-in-ouagadougou (30 May 2019). 
times, most heavily during the opening paragraphs of the speech in which he claimed he and his audience both belonged to a post-colonial, future-oriented generation that refuses to perpetuate the perceptions of the past. Invoking the shared belonging to the same generation is supposed to create commonality across the colonial divide. For Macron as representative of the French side, belonging to this generation involved accepting the "crimes of European colonization" as part of his country's history. Macron explicitly placed himself in a long line of French intellectual criticism of Empire since the 1920s by directly referencing writer André Gide and investigative journalist Albert Londres. ${ }^{23}$ Among all the policy fields addressed during the speech, the return of cultural artefacts displaced during the decades of French colonial rule constituted the most concrete, tangible and radical form of putting the announced departure of an entangled French-African postcolonial generation into practice.

Of course, even this departure would only be a departure of sorts, addressing some legacies of colonialism while leaving others intact. It only speaks to the irresolvable complexities of decolonization that the majority of these objects would have to be returned to the very political entities that European colonialism itself created. Macron's speech as well as the report are predicated upon a bilateral logic of restitution, which is informed by both state-centrism and political realism. Political elites accustomed to the practices of gatekeeping states would certainly not fail to tap the political potential of such cultural transactions, even, or perhaps especially, in cases in which minorities or marginalized groups within their states are concerned. ${ }^{24}$ Interestingly, it also went without comment that the very speech that promised to redress one colonial legacy indulged in the extension of another, for Macron wished for a "strong, influential Francophonie" to make French "the number one language in Africa and maybe even the world". In both cases, the (re-)appropriation of French cultural universals by Africans - "our" heritage and "our" language - is based upon the expectation that this means the tightening and perpetuation of Afro-French entanglements, and the securing, if not extension, of France's cultural and political influence in Africa. To be sure, the pledge of grand-scale restitution would not have happened without Macron and his individual style of doing politics. However, its timing is significant beyond the whim and will of a President intent

23 Cf. Lilyan Kesteloot: Albert Londres et André Gide. Deux témoignages sur l'Afrique des années vingt, in: Revue des litératures du Sud 153 (2004), 88-95; Irene Albers, Andrea Pagni, and Ulrich Winter (eds.): Blicke auf Afrika nach 1900. Französische Moderne im Zeitalter des Kolonialismus. Tübingen 2002.

24 On the gatekeeping postcolonial African state, see Frederick Cooper: Africa since 1940. The past of the present. Cambridge 2002. 
on putting his personal stamp on French policies. It comes at a political moment when France and other Western countries are on the defensive on the African continent - a development that has been described as a transformation from "Françafrique" towards "Chinafrique". ${ }^{25}$ Macron never addresses Chinese investment in Africa directly, but it is present throughout his speech, most obviously in a passage in which he advertises a new African-youth-oriented investment policy that is sensitive to the failures of the past. Translated from diplomatese, he begs his audience to trust the former colonizers, for they have erred in the past but learnt from it. The colonizers of today, however, the "new investors, with companies which provide billions but not one job for Africans, which provide billions while repeating the same mistakes as in the past and which may appear to be easy solutions for today" were bound to "replicate the turmoil, mistakes and sometimes crimes of the past”. Such a warning does not sound too convincing, however, if one considers recent developments in the field of art and museum politics in West Africa. In December 2018, the Museum of Black Civilizations was opened in Dakar, the capital of Senegal - a state-of-the-art museum on African soil, subscribing to a decolonial agenda and providing ample space for African artefacts, erected with substantial funding from China. Such an intrusion of Chinese cultural diplomacy into French-speaking West Africa obviously constitutes a challenge to France, and it may well have promoted the rediscovery of artworks and cultural artefacts as the useful diplomatic tools they have been in the past, during colonial rule and after. ${ }^{26}$ At a time of intense competition and renewed scramble over investments and influence in Africa, Macron wants "Africa to be a priority of French economic diplomacy". In such a situation it is surely no disadvantage to have thousands of objects available for potential restitution as supple tools for a cultural diplomacy that prepares, supports, eases, and complements more material French and European interests in Africa. Such awareness to the context of the pledge should caution against taking restitution as, above all, a disinterested moral politics of decolonization. It still forms part of the cultural and political economy of Françafrique and its transformation into a relationship on more coeval terms.

25 Brian Tourré: De la "Françafrique" à la "Chinafrique". Quelle place pour le développement africain? Paris 2012.

26 See e.g. Sarah van Beurden: The Art of (Re)possession. Heritage and the Cultural Politics of Congo's Decolonization, in: Journal of African History 56 (2015), 143-164. See also the theme issue of the European History Yearbook 2016 on the material culture of modern diplomacy, especially Harriet Rudolph: Entangled Objects and Hybrid Practices? Material Culture as a New Approach to the History of Diplomacy, in: European History Yearbook 17 (2016), 1-28. 


\section{Pressure on Presidential Demand: The Sarr/ Savoy-Report}

Concerning the scope and practice of restitution, the Ouagadougou speech had left several backdoors open, which the Sarr/Savoy-report intended to slam shut. Macron restrained his promise "to do everything possible to bring them back". Further, he considered temporary return and "circulation" 27 a viable option and emphasized that the objects' safety and care after return would be matters of serious consideration. Felwine Sarr and Bénédicte Savoy seized the opportunity of their mandate to render these three options as non-viable as possible. They used the report to increase moral pressure and commit Macron to his pledge, rein in the potential for diplomatic bargaining and "think of restitutions as being something more than a mere strategic maneuver". ${ }^{28}$ Sensitive to the late 1970 s terminological quarrels over the legal, historical, and political implications of "restitution" versus "return", Sarr and Savoy leave no doubt that restitution implies "the recognition of the illegitimacy of the property". Consequently, speaking of restitution means speaking of "justice, or a re-balancing, recognition, of restoration and reparation". The "circulation" of objects, envisioned by Macron in his letter of mission and benevolently offered by major European museums under the guise of "shared heritage", ${ }^{29}$ is rejected as a strategic manoeuver that avoids the necessary transfer of legitimate ownership and merely perpetuates European control over the objects and the status of the "dispossessed cultures" as supplicants of Europe.

Sarr and Savoy remove the ambiguity contained in the oxymoron of "temporary restitutions" by accepting this practice only as a preliminary solution until the legal and institutional prerequisites for definitive restitution of cultural heritage back to Africa are put in place. Their report further disputes the entrenched objection that African states lacked the knowledge and institutional

27 See the preamble of his letter of mission to Sarr and Savoy, which reiterates the aim of "restitutions temporaires ou définitives du patrimoine africain" already mentioned in the speech and favours "une action déterminée en faveur de la circulation des oeuvres", facsimilated in Sarr/Savoy: Restitution of African Cultural Heritage, 107-108.

28 Sarr/Savoy: Restitution of African Cultural Heritage, 22.

29 See e.g. Hermann Parzinger: Geteiltes Erbe ist doppeltes Erbe, in: Frankfurter Allgemeine Zeitung, 16 October 2016, URL: https://www.faz.net/aktuell/feuilleton/shared-heritage-geteilteserbe-ist-doppeltes-erbe-14481517.html?printPagedArticle=true\#pageIndex_0 (30 May 2019); Sarah van Beurden: The pitfalls of "shared heritage”, URL: https://blog.uni-koeln.de/gssc-humboldt/ the-pitfalls-of-shared-heritage/ (30 May 2019); Thomas Thiemeyer: Kulturerbe als "Shared Heritage” (I). Kolonialzeitliche Sammlungen und die Zukunft einer europäischen Idee, in: Merkur 829 (2018), 30-44. 
infrastructure to provide appropriate custody for the returned objects as a neocolonial myth of alleged African incapacity. Amongst others, they refer to the "ultra-modern" Museum of Black Civilizations in Dakar to contest this myth. Above all, Sarr and Savoy propose concrete criteria and a timeline for action that is oriented along the five-year frame set by the Macron moment but seek to establish structures that prevent the "historical window" opened by Macron from ever being shut again. ${ }^{30}$ The foremost criterion for determining which objects qualify for restitution is not provenance or the concrete historical context but the time of acquisition. A first group comprises all those objects that are to be restituted in a swift and wholesale manner without any further research into their provenance, because they were "taken by force or presumed to be acquired through inequitable conditions" within the decades defined as colonial period between 1885 and 1960. This pertains to everything acquired in the context of French military aggression or scientific expeditions, through collection by military personnel or colonial administrators but also to objects that were once loaned by African institutions and never returned. A second category foresees previous research into the provenance of objects that probably stem from colonial contexts but were acquired post-1960 or presented to the museum as a gift e.g. by later generations of families involved with the Empire. A final category consists of objects that should remain within French collections, provided their transaction rested upon documentable and agreed consent or followed the rules concerning illicit trafficking of cultural objects established by UNESCO since 1970.

Apart from defining the colonial period between 1885 and 1960 as a general context of injustice, the Sarr/Savoy-report applies to the colonial context the principle of reversing the burden of proof that was laid down in the 1995 UNIDROIT convention on stolen or illegally exported cultural objects. No longer shall the claimaint have to prove that a certain object was illegally taken; instead, the possessing institution must produce, as Sarr and Savoy put it, "explicit evidence or information witnessing to the full consent on the part of the owners or initial guardians of the objects under question. ${ }^{31}$ This is a very important step to put the historically asymmetrical relationship between claimants and museums on a more equal footing. And given the fact that thousands of colonial objects in European museums lack sufficient documentation as to their provenance and acquisition, the reversal of proof challenges the established

30 On the following, see Sarr/Savoy: Restitution of African Cultural Heritage, 61-69.

31 Sarr/Savoy: Restitution of African cultural Heritage, 58. For a similar demand within the German debate, see Jürgen Zimmerer: Kulturgut aus der Kolonialzeit - ein schwieriges Erbe?, in: Museumskunde 80/2 (2015), 22-25. 
practice that objects, if in doubt of their origin, should remain in their current location. To be sure, Sarr and Savoy did not propose an automatism of proactive restitution once French law has been changed accordingly. Such proactive restitution is only suggested for an attached list of carefully selected objects including 26 bronzes looted from the Palaces of Abomey in 1892, which Macron promised to return immediately to the state of Benin from the holdings of the Musée Quai Branly. In all other cases, restitution or research into their provenance should only be undertaken after a demand for restitution was actively put forward from an African party. ${ }^{32}$

In a recent critical and mildly polemical, yet close and insightful, reading of the Sarr-Savoy-report, German journalist Patrick Bahners put special emphasis on the bureaucratic and political character of the document. ${ }^{33}$ Although authored by an art historian and an economist affiliated with various academic institutions, the report is not a scholarly but rather a political enquiry. Facsimilated letters of mission accompanied the published report, testifying to everyone that it was mandated by the President of France. The report draws repeatedly and directly upon the Ouagadougou speech and tries to provide an authoritative and definitive exegesis of they key terms deployed in Macron's pledge. Sarr and Savoy do not question the limitations of the mandate: Since Macron only touched upon the dispersal of Africa's cultural heritage, the report is not concerned with the similar or different fate of objects acquired in other territories under French imperial domination. Disregarding the Middle Eastern, Asian and Oceanian parts of the French Empire, ${ }^{34}$ albeit for pragmatic reasons, runs the risk, however, of entrenching once more the image of Africa as the plundered continent. Sarr and Savoy also tailor the restitution of Africa's cultural heritage as a specifically French problem. Although they repeatedly draw upon examples from Belgian, British and German overseas imperialism to underline the magnitude and European dimension of the problem, they emphasize the specific history and "particular responsibilities of France" in the world region of Africa that are, in their eyes, "much different than those left by Great Britain, Belgium, Germany, or Italy". ${ }^{35}$ This intentional nationalization is supposed to block the political escape

32 Sarr/Savoy: Restitution of African Cultural Heritage, 61.

33 Patrick Bahners: Französisches Ausleerungsgeschäft. Der "Bericht über die Restitution afrikanischen Kulturerbes", in: Merkur 838 (2019), 5-17, here 6 and 9.

34 See e.g. Christine Howald: The Power of Provenance. Marketing and Pricing of Chinese Looted Art on the European Market (1860-1862), in: Bénédicte Savoy, Charlotte Guichard, and Christine Howald (eds.): Acquiring Cultures. Histories of World Art on Western Markets, Berlin 2018, 241-259.

35 Sarr/Savoy: Restitution of African Cultural Heritage, 3. 
route into a strategic Europeanization or internationalization of the problem. Yet, it frames imperialism as essentially a nationalist project and tends to underestimate the transimperial and entangled character of the historical phenomenon under discussion, as embodied e.g. in the existence of international markets for African ethnographica and artefacts.

The authors regard Macron's personal commitment as a unique chance to achieve a breakthrough in the decades-long stalemate concerning the restitution of Africa's displaced cultural heritage. This can be gleaned from the report's immediate and unpolished publication as a pdf-file, suggesting that Sarr and Savoy regarded their analysis and recommendations as too urgent to tolerate any further delay through regular publication. But the impact of the Macron moment is perhaps best discernible in Bénédicte Savoy's public contributions to the debate. In her inaugural lecture presented to the Collège de France in March 2017, Savoy sketched the outlines of the daunting intellectual project to reconnect the artefacts and artwork in Europe's museums to the places, people and cultures of their origin. The adequate mode in which this "provenance of culture" needed to be approached was, in her recommendation, "introspection". Such introspection included, amongst others, a critical reflection of the language of heritage, the analysis of the historical provenance of objects and the reconnection to present-day descendants of historical source communities. Savoy also addressed openly what introspection did not mean: "self-flagellation, or the hurried and muddled restitution of objects of whom some outside Europe, too, think they are better preserved in Europe, at least for the moment." ${ }^{36}$ In early 2017, research into the provenance of ethnographic collections was just about to become established as a progressive venture in the museum world. ${ }^{37}$ The possible future of heritage seemed best approached through reconstructing the history of how objects came to "us". Then came Macron, whom Savoy welcomed as the herald of a "restitution revolution". 38 The Macron moment was an

36 Bénédicte Savoy: Die Provenienz der Kultur. Von der Trauer des Verlusts zum universalen Menschheitserbe. Berlin 2017, 54.

37 See Bernhard Gissibl: Raubkunst, die nächste Debatte, in: Frankfurter Allgemeine Zeitung, 24 April 2017, URL: https://www.faz.net/aktuell/feuilleton/voelkerkundemuseen-beginnen-mit-pro venienzforschung-14984217.html (30 May 2019); Larissa Förster: Plea for a more systematic, comparative, international and long-term approach to restitution, provenance research and the historiography of collections, in: Museumskunde 81/1 (2016), 49-54; Larissa Förster et al. (eds.): Provenienzforschung zu ethnografischen Sammlungen der Kolonialzeit. Positionen in der aktuellen Debatte. Berlin 2017.

38 Bénédicte Savoy: The restitution revolution begins. President Macron is ushering in a new era for the return of displaced heritage (16 February 2018), URL: https://www.theartnewspa per.com/comment/the-restitution-revolution-begins (30 May 2019). 
opportunity to be seized. It should not lose any of its momentum to the complexities of historical circumstance.

\section{Historical Injustice, Historical Complexities}

Indeed, the official and political character of the report shaped its genesis, content, aim and argument in decisive ways. Since time for travel and research was limited and the report's mandated aim was to facilitate restitution, the authors and their team only visited such African countries with experiences of or an ongoing debate about restitution, or with a receptive museographic or cultural landscape - in other words, states where the promise of restitution could reckon with resonance. ${ }^{39}$ Since the mandated aim was to facilitate restitution, the report subordinated complex past historical engagements to the achievement of the laudable goal to right historical injustices. The intellectual endeavour of analysing and explaining human diversity that also found expression in ethnographic collecting and the disciplines of anthropology and ethnology does not feature in the report. These disciplines, their practices and their intentions are shorn of their ambiguities $^{40}$ : They were "born from an era of violence", capitalized on the opportunities provided by European colonialism and realised their scientific value in the services they rendered to colonial rule.

Since the report's main recommendation is swift and thorough restitution "without any supplementary research" regarding the provenance of objects obtained from Africa between 1885 and 1960, Sarr and Savoy have no need to question or distinguish their provenance. Neither the various ways in which they became art or ethnographic objects nor their changing and often disputed

39 The states visited were Benin, Senegal, Mali and Cameroon, see Sarr/Savoy: Restitution of African Cultural Heritage, 4, fn. 6.

40 For critical and nuanced readings see e.g. Hugh Glenn Penny: Objects of Culture. Ethnology and Ethnographic Museums in Imperial Germany. Chapel Hill 2002; Andrew Zimmerman: Anthropology and Antihumanism in Imperial Germany. Chicago 2001; Andrew Zimmerman: Bewegliche Objekte und globales Wissen. Die Kolonialsammlungen des Königlichen Museums für Völkerkunde in Berlin, in: Rebekka Habermas and Alexandra Przyrembel (eds.): Von Käfern, Märkten und Menschen. Kolonialismus und Wissen in der Moderne. Göttingen 2013, 247-258; Hugh Glenn Penny and Matti Bunzl (eds): Worldly Provincialism. German anthropology in the age of empire. Ann Arbor 2003; Anja Laukötter: Von der „Kultur“ zur „Rasse“ - vom Objekt zum Körper? Völkerkundemuseen und ihre Wissenschaften zu Beginn des 20. Jahrhunderts. Bielefeld 2007; Han F. Vermeulen: Before Boas. The Genesis of Ethnography and Ethnology in the German Enlightenment. Lincoln 2015; Benoit de L'Estoile: From the Colonial Exhibition to the Museum of Man. An alternative genealogy of French anthropology, in: Social Anthropology 11 (2003), 341-361. 
ontological status before and after transfer and integration into European collections matters. The varying intentions of collectors are also considered irrelevant. All this may indeed be negligible, for looting, even with the honest intention of salvage collecting in the interest of mankind, still remains looting. The report is also not interested in the strategies, experiences, or agencies of those who were deprived of their material culture. Restitution without accompanying research into provenances runs the risk of effacing historical African agency in the confrontation with colonial asymmetries, violence and racism. It glosses over the results of years of historical research into the weaknesses of the colonial state, the regionally varying reach of its claim to power, its makeshift alliances, and the widespread use of material culture not to acknowledge the asymmetries of colonial rule but to assert claims and establish coevalness. While in 2017 Savoy was still interested if and "how much blood stained the objects kept in European museums", ${ }^{41}$ these bloodstains were taken for granted in the report one year later. Thousands of different and differently acquired objects are qualified wholesale in homogenizing and politically charged categories such as "looted", "art", and "heritage". The scholarly debate and literature on "entangled objects", conquest and collecting, captured heritage, or trans-imperial cultural flows does not feature in the report, nor is it necessary for the report's foremost aims. ${ }^{42}$

Instead, Sarr and Savoy situate French imperialism in Africa within a deep history of warfare, conquest and looting since Greek and Roman antiquity. They emphasize the intellectual, aesthetic and economic appropriation of cultural heritage as a "natural correlate", 43 if not tool of empire. Indeed, their approach is predicated upon a homology or a structural dependency between the asymmetries of imperial conquest and rule and the transfer of material culture. The latter has no agency or rationality of its own but is conceived of as an effect of empire. With looting declared as the standard mode of acquisition, it is of minor importance to query e.g. the prevalent ideas and conceptions of justice or legitimate trade and exchange that were relevant in concrete historical

41 Ein unlösbarer Widerspruch, in: Süddeutsche Zeitung, 20 July 2017, URL: https://www.sued deutsche.de/kultur/benedicte-savoy-ueber-das-humboldt-forum-das-humboldt-forum-ist-wietschernobyl-1.3596423?reduced=true (30 May 2019).

42 See e.g. Nicholas Thomas: Entangled Objects. Exchange, Material Culture, and Colonialism in the Pacific. Cambridge/Mass., London 2001; Maja Jasanoff: Edge of Empire. Conquest and Collecting in the East, 1750-1850. New York 2006; Zachary Kingdon: Ethnographic Collecting and African Agency in Early Colonial West Africa: A Study of Trans-Imperial Cultural Flows. London 2019; Douglas Cole: Captured Heritage. The Scramble for Northwest Coast Artefacts. Vancouver 1985; Tom Flynn and Tim Barringer (eds.): Colonialism and the Object. Empire, Material Culture and the Museum. London 1998.

43 Sarr/Savoy: Restitution of African Cultural Heritage, 10. 
situations. ${ }^{44}$ Likewise, the variety of contact zones in which colonial encounters took place, the local and regional micro- and mesocontexts with their instabilities and often shifting asymmetries are rendered less relevant, ${ }^{45}$ respectively they are subordinated epistemologically to a totalizing macrostructure of imperial colonialism as an all-determining context of violence, injustice, and racism. The framing categories are not analytical ones, applied with the intention to capture the multiplicity of object biographies and trajectories. They are political categories applied in order to facilitate a political decision. The restitution report shows little interest in historical ambiguities or the existence of historical contact zones or common grounds, their workings and dynamics.

\section{Afrotopia}

If the restitution report is less interested in the possible pasts of the objects, this is because its prime interest lies with their possible futures. The relative eclipse of the entangled colonial history of the objects is perhaps necessary to realize their Afrotopian potential and purpose. Set free from their imprisonment in Western museums, the re-placed cultural heritage has to fulfil an at least twofold task: First, it has to serve as a foundation for a new "relational ethics" between Africa, Europe and the rest of the world. After return and re-appropriation, Africa's cultural heritage should not inspire their communities or regions of origin alone. As sources of human creativity and ingenuity, the objects are supposed to circulate "within a temporality, a rhythm and a meaning, placed on them by their legitimate owners" ${ }^{46}$ as well as "within both a continental and global geography". ${ }^{47}$ Sarr and Savoy insist that the objects, having for decades served as markers of primitivism, backwardness, primeval originality, natural art, or authentic expressions of static "cultures" in European collections, will not be resigned to new forms of "enslavement to a cultural identity" again after their return. Therefore, the "freedom", newfound mobility and creative potential of the objects is underlined again and again

44 See Larissa Förster: Wer fühlte sich beraubt? In: Frankfurter Allgemeine Einspruch, URL: https://einspruch.faz.net/recht-des-tages/2018-11-24/wer-fuehlte-sich-beraubt/172449.html (30 May 2019).

45 For the broad analytical canvas of the diversity of cultural encounters in European expansion see Jürgen Osterhammel: Kulturelle Grenzen in der Expansion Europas, in: id.: Geschichtswissenschaft jenseits des Nationalstaats. Studien zu Beziehungsgeschichte und Zivilisationsvergleich. Göttingen 2001, 203-239.

46 Sarr/Savoy: Restitution of African Cultural Heritage, 38.

47 Sarr/Savoy: Restitution of African Cultural Heritage, 39. 
throughout the report, probably to dispel the impression that the reappropriation of the objects by their communities of origin could result in another freezing and immobility of the objects. This reappropriation is the second main task assigned to the objects, and Sarr and Savoy cannot emphasize enough that such putting back into their legitimate place has nothing to do with re-essentialisation or the cultural provincialization of once universally acknowledged art. The report abounds with a vocabulary of dynamism, departure, and possibility. Restitution does not mean dispersal but a "spatial explosion of cultural heritage"; they emphasize the objects' "power of germination" and their capacity to both reveal hitherto obscured epistemogonies as well as to give rise to new forms of meaning and knowledge. ${ }^{48}$ Sarr and Savoy leave no doubt that objects that have been exposed to a "plurality of semantic, symbolic, and epistemological dispositives" over the last century do not allow for easy re-integration and re-appropriation. They return as a "different same”. Yet, depending on the respective social contexts in which they are re-inserted, they have vital tasks to fulfil: they are supposed to serve as materializations that crystallize lost memories, give recourse to past creativity and ingenuity for young generations, and generally help with the "self-reinvention" of social entities. ${ }^{49}$ Indeed, the restituted objects are fraught with expectations: as "operators of a relational and plastical identity", 50 they "could help to re-draw transnational territorial borders thereby reoccupying spaces of the circulation of communities, but also so as to help expand the circulation of these objects on a more continental and global scale. Furthermore, reappropriating for oneself, as a culture, allows for a toppling of colonial categories, thereby helping to re-fluidify fixed geographies and to invert the colonial hegemonic relationship in place that was instituted by a fixed location of the cultural objects along with monopoly of the discourse concerning them". ${ }^{51}$ The passages on the manifold functions of restituted objects within African societies resonate heavily with Felwine Sarr's programme for cultural reinvention as laid down in his manifesto published under the title Afrotopia in French in 2016. The displaced cultural heritage counts among the many sources envisioned by Sarr to help overcome externally-imposed identifications and guide Africa to retrieve its identity. ${ }^{52}$

It is not difficult to point out the homogenizing, "continentalist" implications of this Afrotopian agenda, question the enormous and partially contradictory expectations burdened upon the returning heritage, or counter the

48 Sarr/Savoy: Restitution of African Cultural Heritage, 33, 35, 44.

49 Sarr/Savoy: Restitution of African Cultural Heritage, 32.

50 Sarr/Savoy: Restitution of African Cultural Heritage, 35.

51 Sarr/Savoy: Restitution of African Cultural Heritage, 38.

52 Felwine Sarr: Afrotopia. Paris 2016. 
optimistic future programme of restitution with a more pessimistic scenario. It may well be the case that the re-integration into African contexts will not result in peaceful circulation across borders and the irenic scrambling of static social identities. Like any other form of heritage, the cultural variety will also be subject to contestation, rival epistemologies, perilous commoditization, and confrontative claims on objects whose significance, after, all, not only stems from their social and cultural functions but also from their often enormous economic value on art and touristic markets. ${ }^{53}$ Indeed, it remains an open question how the transcending of boundaries and re-fluidifying of fixed geographies will be reconciled with the claims and rationalities of nation states who are key actors when restitution is conceived of as bilateral negotiation, as the report does. There is also a tension between the Afrocentric and Afropolitan assignments to Africa's cultural heritage. Still, the epistemic remobilization of thousands of objects that have for decades been rendered immobile and invisible in the storerooms of European museums and their reinvention as ambassadors of a new Afropolitanism is a timely and fascinating vision, and one can only support and admire the optimistic spirit in which the report is written.

\section{Reverberations across the World Museum World}

As yet, the world still waits to see how much of this optimistic spirit has permeated the Palais de l'Élysée. While the main addressee of the report has remained silent for months: and appears to withdraw, at least partially, from his earlier commitment. $^{54}$ Sarr and Savoy's recommendations caused a tremendous stir within the museum world, in the relevant academic disciplines, among postcolonial activists, on social media, and in newspapers and other news outlets. ${ }^{55}$ The spectrum of

53 The economic dimension of African heritage is obvious, but remains glaringly unaddressed in the current debate, see Thomas Thiemeyer: Kulturerbe als "Shared Heritage" (II). Anerkennungsfragen, in: Merkur 830 (2018), 85-92.

54 See Vincent Noce: France retreats from report recommending automatic restitution of looted African artefacts, in: The Art Newspaper, 5 July 2019, URL: https://www.theartnewspa per.com/news/france-buries-restitution-report (25 July 2019).

55 For a comprehensive survey of reactions across academia, media, politics and the museum world see Margareta von Oswald: The "Restitution Report". First Reactions in Academia, Museums, and Politics (15 January 2019), URL: http://www.carmah.berlin/reflections/restitu tion-report_first-reactions/ (30 May 2019). The debate is closely monitored by the Colognebased blog "Wie weiter mit Humboldts Erbe?" URL: https://boasblogs.org/humboldt/ and in the reflections-section of the Berlin-based Centre for Anthropological Research on Museums and Heritage, URL: http://www.carmah.berlin/reflections/. 
reactions included everything from scathing indictment ${ }^{56}$ to diplomatic and depoliticizing differentiation, strategic embracement, ${ }^{57}$ polite acknowledgement, and enthusiastic praise. Self-proclaimed "global thought leader in international arts and culture" Adrian Ellis regarded the report as more than just another salvo but even as the opening of "a new and possibly decisive battle in the long war" between Western museums and those critics who regard them as treasure houses of largely looted non-European holdings. ${ }^{58}$ Similarly, Jörg Häntzschel of Germany's quality daily Süddeutsche Zeitung, a journalistic proponent of the report, commended its authors for having elevated the debate over the adequate treatment of colonial objects to a new level. ${ }^{59}$

In any case, the report provoked reverberations beyond words and rhetorical declarations across Europe. This was perhaps the least so in Britain, where the directors of the most important museums reacted quickly, cautiously and, so far, defensively. ${ }^{60}$ The British Museum, engulfed for decades in debates about the restitution of some of its most valuable holdings, launched a monthly gallery talk on "collecting histories" in autumn 2018. While these talks convey the diverse and often non-violent provenance of the collections, British Museum director Hartwig Fischer has, so far, only been quoted with statements that confirm his determination to preserve the integrity and universal claim of its collections. Colleagues like Tristram Hunt of the Victoria \& Albert Museum were slightly more accommodating in that they acknowledged the need for transparency about their collections and promised increased cooperation and the long-term loan of artefacts. At the same time, Hunt called for more

56 Erhard Schüttpelz: Everything must go: Looting the Museum as Compensation for Looting the World. Raubkunstforschung als angewandte Wissenschaft, URL: https://boasblogs.org/ humboldt/everything-must-go-looting-the-museum-as-compensation-for-looting-the-world/ (25 July 2019).

57 See e.g. Tristram Hunt, Hartmut Dorgerloh, Nicholas Thomas, "Restitution Report: museum directors respond”, The Art Newspaper, 27 November 2018, https://www.theartnewspaper. com/comment/restitution-report-museums-directors-respond (30 May 2019).

58 Adrian Ellis: Museums in the changing world order: Restitution to Africa reaches tipping point (5 April 2019), URL: https://www.theartnewspaper.com/comment/museums-in-thechanging-world-order-restitution-to-africa-reaches-tipping-point (30 May 2019).

59 Jörg Häntzschel: Gebt sie zurück!, in: Süddeutsche Zeitung, 21 November 2018, URL: https://www.sueddeutsche.de/kultur/restitution-von-raubkunst-gebt-sie-zurueck-1.4220674 (30 May 2019).

60 See Oswald, Restitution Report; Ruth Maclean: Bronzes to Benin, gold to Ghana ... museums under fire on looted art, in: The Observer, 2 December 2018, URL: https://www.theguar dian.com/culture/2018/dec/02/british-museums-pressure-give-back-looted-african-art-treas ures (30 May 2019). 
development aid to create a satisfactory cultural infrastructure in the global South and cautioned against making museums the "instruments of government". ${ }^{61}$

Hunt's concern over state interference in museum affairs is probably widely shared across the European museum world. ${ }^{62}$ Museums in the Netherlands used the absence of a national policy on restitution to take proactive steps themselves. In March 2019, the Nationaal Museum van Wereldculturen (NMVW) issued a catalogue of rules and principles under which claimants can request the return of cultural objects from the museum's holdings. ${ }^{63}$ Just a few days later, the Amsterdam Rijksmuseum, an institution with substantial collections from Sri Lanka and Indonesia, came forth with an initiative intended to surpass the setting of conditions by the NMVW. Announcing that merely waiting for claimants is not enough and that the Netherlands started embarrassingly late with the return of colonial objects, the museum sent a senior official to Sri Lanka to discuss the return of objects looted from the island in the colonial era. These initiatives show that, in the Netherlands as anywhere else, strategic considerations prevail. The Principles and Process for Addressing Claims for the Return of Cultural Objects set up by the NMVW, for example, have been criticized for shifting the onus of proof once more onto the claimants who, for example, could be asked to provide evidence for a "persistence of belief" or "culture" as proof that an object is truly theirs. Such dictating of conditions does not signal a wholehearted embrace of restitution but must be regarded as a pre-emptive step to retain control and agency with a view to official state policies and the development of criteria for restitution on a national level. The same is true for the Rijksmuseum, which used its relative latecoming as the second mover among Dutch institutions to claim the morally higher ground vis-àvis the NMWV, at least for the time being. However, as strategic and awkwardly phrased as the provisions of the NMWV principles may be, they do alert us to the unresolved tensions inherent in the much celebrated reversal of the burden of proof. What obligations does it precisely entail, and how is agency

61 Tristram Hunt, Hartmut Dorgerloh, Nicholas Thomas, "Restitution Report: museum directors respond”, The Art Newspaper, 27 November 2018, https://www.theartnewspaper.com/com ment/restitution-report-museums-directors-respond (30 May 2019).

62 The President of the German Federation of Museums (Deutscher Museumsbund) Eckart Köhne, for example, warned against state interference in the internal policies of museums by arguing that, in Germany, this last happened during the Nazi regime between 1933 and 1945 (Statement as a member of a panel discussion on "sensitive objects", held at the Landesmuseum Mainz, 25 April 2019.)

63 See https://www.afrikamuseum.nl/nl/teruggave-van-culturele-objecten-principes-en-proc essen (30 May 2019). 
distributed in the process of producing evidence for legitimate or illegitimate ownership? ${ }^{64}$ And can museums be expected to enter into in-depth provenance research of any object claimed without somehow previously establishing the claimant's entitlement to do so? Such questions concerning the legitimate heir will inevitably come up as soon as the "Africa" of intellectual debate falls apart into individuals, groups, communities and states who actively start reclaiming objects as "their" heritage.

\section{The Macron Moment in the Federalized German World Museum World}

In Germany, Macron's initiative and the Sarr/Savoy-report were received in the context of an already vitriolic and polarized debate about the country's adequate addressing of its colonial past. One strand of this debate has focussed on the question of a formal apology and the official recognition as genocide of Germany's brutal war of annihilation waged in its Namibian colony between 1904 and 1907, a protracted diplomatic process that has burdened GermanNamibian relations at least since the centenary commemorations of the war's outbreak in 2004. ${ }^{65}$ A second strand consisted of a number of local initiatives, driven by academic projects, postcolonial activist groups or both together, who addressed aspects and traces of Germany's colonial past in concrete urban contexts. Frequently taking up the critical "think global, act local"-spirit of older forms of Third World activism, these initiatives retrieved local historical

64 Also the North American Graves Protection and Repatriation Act (NAGPRA), often lauded as a model for handling restitution in the European colonial debate, is struggling with these issues, see e.g. Helen A. Robbins: In Consideration of Restitution. Understanding and Transcending the Limits of Repatriation under the Native American Graves Protection and Repatriation Act (NAGPRA), in: Louise Tythacott and Kostas Arvanitis (eds.): Museums and Restitution. New Practices, New Approaches. London, New York 2014, 105-121.

65 For a survey see Henning Melber and Reinhart Kößler: Völkermord und was dann? Die Politik deutsch-namibischer Vergangenheitsbearbeitung. Frankfurt/M. 2017; for the historiographical dimension of the debate over genocide see Christiane Bürger: Deutsche Kolonialgeschichte(n). Der Genozid in Namibia und die Geschichtsschreibung der DDR und BRD. Bielefeld 2017; Jürgen Zimmerer and Joachim Zeller (eds.): Völkermord in Deutsch-Südwestafrika - Der Kolonialkrieg (1904-1908) in Namibia und seine Folgen. Berlin 2003; Isabel Hull: Absolute Destruction. Military Culture and the Practices of War in Imperial Germany. Ithaca 2006; on the divergent memorialization in Germany and Namibia Larissa Förster: Postkoloniale Erinnenungslandschaften. Wie Deutsche und Herero in Namibia des Kriegs von 1904 gedenken. Frankfurt/M. 2010. 
connections to overseas colonialism and addressed a variety of practices, attitudes and institutions that still awaited adequate decolonization. Among these were e.g. street names that glorified brutal colonial militaries and officials but also the local and provincial legacies of ethnographic collecting in the state capitals of a federally organized Germany.

In many cities, museums actively cooperated with such initiatives in the investigation of their colonial histories by making their archives accessible. ${ }^{66}$ But certainly the most significant strand has crystallized around the flagship cultural project of reconstructing the former Hohenzollern palace in the heart of Berlin and opening it as a grand cultural institution named the Humboldt-Forum, supposed to showcase globalized Germany's cosmopolitanism by, amongst others, displaying items from the ethnographic collections of the Prussian and German state. ${ }^{67}$ These collections comprise tens of thousands of objects from all over the world since the early modern period and include artefacts collected in nonGerman colonial contexts, such as a substantial number of the famous Benin Bronzes, the most notorious example of looted yet not restituted art from Africa. But above all, the Berlin ethnographic museum owns considerable holdings from the decades of German colonial rule in Africa, Asia and Oceania between 1884 and 1918. After 1889, the Berlin ethnographic museum functioned as the central institution collecting all objects acquired in the official colonial contexts of conquest, administrative duty, or military and state-sponsored expeditions. This monopoly resulted in a skyrocketing increase of colonial objects during these years, particularly from Africa. ${ }^{68}$ Obviously, this official role constitutes a special and particularly deep involvement of the Berlin collections into Germany's overseas colonialism. The responsibility arising from this involvement, however, needs yet

66 From a flourishing field of initiatives, websites and publications see e.g. the websites of Berlin, Hamburg, Heidelberg, or Freiburg postkolonial, further Bernd-Stefan Grewe, et al.: Freiburg und der Kolonialismus. Vom Kaiserreich bis zum Nationalsozialismus. Freiburg 2018; Eva Bahl et al. (eds.): Decolonize München. München 2015; Felix Brahm and Bettina Brockmeyer (eds.): Koloniale Spurensuche in Bielefeld und Umgebung. Bielefeld 2014; Marianne Bechhaus-Gerst and Anne-Kathrin Horstmann (eds.): Köln und der deutsche Kolonialismus. Eine Spurensuche. Köln, Weimar, Wien 2013.

67 See Peter-Klaus Schuster and Horst Bredekamp (eds.): Das Berliner Humboldt-Forum. Die Wiedergewinnung der Idee. Berlin 2016; AfricAvenir (ed.): No Humboldt 21! Dekoloniale Einwände gegen das Humboldt-Forum. Berlin 2017; Friedrich von Bose: Das Humboldt-Forum. Eine Ethnografie seiner Planung. Berlin 2016; Karl-Heinz Kohl et al.: Das Humboldt-Forum und die Ethnologie. Ein Gespräch zwischen Karl-Heinz Kohl, Fritz Kramer, Johann Michael Möller, Gereon Sievernich, Gisela Völger. Frankfurt/M. 2019.

68 Christine Stelzig: Afrika am Museum für Völkerkunde in Berlin 1873-1919. Aneignung, Darstellung und Konstruktion eines Kontinents. Herbolzheim 2004, 15. 
to be fully and explicitly admitted and addressed by the Forum's managers, who have long engaged in outright denial of or circumstantial whataboutism with regard to problem. ${ }^{69}$ More recently, they have taken to weighing up a long history of benign, enlightened and cosmopolitan interest in the "Other" against a short, imperialist and violent aberration of colonial collecting, without acknowledging that one was implicated in the other. ${ }^{70}$

These years-long attempts at evading, eluding, belittling and obscuring the colonial problem of the Humboldt-Forum have not only contributed to an unprecedented media attention to colonial topics and fuelled the criticism raised by Berlin-based postcolonial initiatives and academics. They also provided a peculiarly fertile ground for the urgency and radicalism of the Macron moment. After all, the Humboldt-Forum faces even greater time pressures than does Macron, as it is due to open in late 2019. If this resulted in a doubling of urgencies in the German case, the Sarr/Savoy-report was also received with special attention, for it could be read as a comment on the Humboldt-Forum by a former member of its scientific advisory board. Bénédicte Savoy's spectacular resignation in July 2017 was accompanied by public accusations of fundamental misconceptions and a strategic unwillingness to address the problematic provenance of the Berlin ethnographic collections. The refusal of Berlin officials to sufficiently acknowledge the problem of colonial provenances has surely contributed its share to the uncompromising character of the report's recommendation. Moreover, Savoy's scathing criticism has tainted the substantial efforts at cooperative provenance research undertaken by the Berlin ethnological museum since 2016. ${ }^{71}$ They appear, perhaps unjustified, as first and foremost strategic concession to the ever-mounting public criticism.

69 Hermann Parzinger: Konzept zur Präsentation der außereuropäischen Sammlungen im Humboldt-Forum 2008, in: Baessler-Archiv 59 (2011), 113-184, esp. 122.

70 See e.g. "Ich lehne diese Argumentation der Gleichsetzerei ab". Interview with Horst Bredekamp in Deutschlandfunk Kultur, 26 November 2018, URL: https://www.deutschland funkkultur.de/bredekamp-widerspricht-savoys-empfehlungen-ich-lehne-diese.1013.de.html? dram:article_id=434280 (30 May 2019).

71 These efforts at unveiling "shared histories of objects" have dealt with, above all, collections acquired during warfare in colonial Tanzania and are intended to develop a "framework concept" for colonial provenance research, see Pilotprojekt: Tansania-Deutschland: Geteilte Objektgeschichten?, URL: https://www.smb.museum/museen-und-einrichtungen/ethnolo gisches-museum/sammeln-forschen/forschung/tansania-deutschland-geteilte-objektge schichten.html (30 May 2019), and Lily Reyels, Paola Ivanov, Kristin Weber Sinn (eds.): Humboldt Lab Tanzania. Objekte aus kolonialen Kriegen im Ethnologischen Museum Berlin. Deutsch-tansanische Perspektiven. Berlin 2018. 
Unsurprisingly, the Sarr/Savoy-report met with reserved and diplomatic public reactions from the directors in charge of the Humboldt-Forum. The Forum's manager Hartmut Dorgerloh welcomed an "overdue" debate and promised to increase provenance research in order to establish if "injustice was done in the process", for "looted art must always be returned". ${ }^{72}$ His colleague Hermann Parzinger, the President of the Prussian Cultural Heritage Foundation, reacted by what has been characterized as "rejection through overembracing"73: he has not directly commented on Sarr and Savoy, but has praised Macron's first statement after the handing-over of the report. On this occasion, Macron once more presented the exchange and circulation of objects as possible forms of cooperation with African states alongside restitution. Sidelining the report itself in favor of Macron enables Parzinger to emphasize the fundamental congruence between Macron's initiative and the cooperative approach to determining the provenance and deciding upon the possible return of colonial objects as practiced by German institutions and their partners. Urging the necessity of dialogue, cooperation, and exchange with formerly colonized societies, he then questioned the juridical feasibility of retroactive restitution. Instead of a legal solution, Parzinger proposed the formation of an international commission to develop ethical standards similar to the Washington Principles on Nazi-Confiscated Art agreed upon in $1998 .{ }^{74}$ Above all, museums must be put in a position to digitize and make accessible their object-related documentation, to conduct provenance research and extend their world-wide networks with other museums and source communities. His contribution concluded with a statement that human remains must by all means be restituted ${ }^{75}-$ a declaration that signals determination and

72 Tristram Hunt, Hartmut Dorgerloh, Nicholas Thomas, "Restitution Report: museum directors respond", The Art Newspaper, 27 November 2018, https://www.theartnewspaper.com/com ment/restitution-report-museums-directors-respond (30 May 2019).

73 Margareta von Oswald: The "Restitution Report”. First Reactions in Academia, Museums, and Politics (15 January 2019), URL: http://www.carmah.berlin/reflections/restitution-report_ first-reactions/ (30 May 2019).

74 These proposals are, however, non-binding. For a model of principles on dealing with colonial cultural and historical objects based upon the Washington Principles see Jos van Beurden: Treasures in Trusted Hands. Negotiating the future of colonial cultural objects. Leiden 2016.

75 Hermann Parzinger: Zeitenwende oder Ablasshandel?, in: Frankfurter Allgemeine Zeitung 29 November 2018, URL: https://www.faz.net/aktuell/feuilleton/debatten/wie-sollte-man-mitkolonialen-kulturguetern-umgehen-15914615-p2.html?printPagedArticle=true\#pageIndex_1 (30 May 2019). 
moral rigour but only states an obvious principle that is already a widely shared ethical consensus across the museum world. ${ }^{76}$

Of course, reactions in Germany have not been restricted to the embracing rejection by the managers of Germany's soon-to-be most egregious cultural institution. Forty years after director-general of UNESCO Amadou-Mahtar M'Bow called upon media "to arouse worldwide a mighty and intense movement of public opinion so that respect for works of art leads, wherever necessary, to their return to their homeland", 77 journalists sympathetic to the cause of restitution immediately popularized the report's recommendation in equally radical headlines (“Gebt alles zurück!"). The report resulted in a further increase of academic workshops and panel discussions on colonial collections. Well over a hundred scholars from history, ethnology and other humanities disciplines published a public appeal in the quality weekly Die Zeit in December 2018 to sympathize with the appeal for restitution and call for a deep and broad societal engagement with German colonialism and the manifold legacies and entanglements it forged across continents. ${ }^{78}$ Just a few days later, high-ranking cultural politicians Michelle Müntefering and Monika Grütters acknowledged the need for a thorough engagement of German society with its colonial past. In an article that was published simultaneously in the quality daily Frankfurter Allgemeine Zeitung and on the website of the German Foreign Office, they appealed to museums to ensure a maximum of transparency about their

76 See e.g. the Recommendations for the Care of Human Remains in Museums and Collections, issued by the German Museums' Association in 2013 (URL: https://www.museumsbund.de/ wp-content/uploads/2017/04/2013-recommendations-for-the-care-of-human-remains.pdf); Larissa Förster and Sarah Fründt (eds.): Human Remains in Museums and Collections. A Critical Engagement with the "Recommendations" of the German Museums' Association (2013), in: H-Soz-Kult (03 February 2017), URL: <www.hsozkult.de/debate/id/diskussionen3902> (27 May 2019); and, from a vast literature, Friedemann Schrenk, Anke Kuper, Anne Marie Rahn, Isabel Eiser: Menschen in Sammlungen. Geschichte verpflichtet, in: Anna-Maria Brandstetter and Vera Hierholzer (eds.): Nicht nur Raubkunst! Sensible Dinge in Museen und universitären Sammlungen. Göttingen 2018, 45-61; Holger Stoecker, Thomas Schnalke, and Andreas Winkelmann (eds.): Sammeln, Erforschen, Zurückgeben? Menschliche Gebeine aus der Kolonialzeit in akademischen und musealen Sammlungen. Berlin 2013.

77 An Appeal by Mr. Amadou-Mahtar M'Bow, Director-General of UNESCO. A Plea for the Return of an Irreplaceable Cultural Heritage to Those Who Created It, in: The Unesco Courier, 31, July 1978, 4.

78 Was wir jetzt brauchen: Für Restitutionen und einen neuen Umgang mit der Kolonialgeschichte. Ein Appell von Wissenschaftlern aus der ganzen Welt, in: Die Zeit, 12 December 2018, URL: https://www.zeit. de/2018/52/kolonialgeschichte-umgang-kunstwerke-restitution (30 May 2019); Rebekka Habermas and Ulrike Lindner: Rückgabe - und mehr!, in: Die Zeit, 12 December 2018, URL: https://www.zeit.de/2018/ 52/kunst-kolonialzeit-rueckgabe-restitution-geschichtspolitik (30 May 2019). 
collections and to openly engage with the return of colonial objects to their societies of origin. ${ }^{79}$ Thereby, they increased the pressure on an institution that had already sought to develop a uniform position on the matter. For example, half a year earlier, in May 2018 and preceding the Sarr/Savoy-report, the German Museums' Association had published preliminary “Guidelines on Dealing with Collections from Colonial Contexts" which has just been republished in summer 2019 after discussion with experts from selected source communities. ${ }^{80}$ While the first edition was characterized by a cautious approach to the "return" of colonial objects, the revised version is marked by a far greater sensitivity to non-European perspectives on the matter. The guidelines do not assume a determinism between colonial context and illegal acquisition, as Sarr and Savoy do. Rather, provenance from a colonial context obliges museums to act with particular sensitivity and meticulous examination. ${ }^{81}$

The guidelines of the German Museums' Association originated from debates that well antedated the Macron moment ${ }^{82}$ and show that we should be careful not to attribute too much impact to the Macron momentum. The same is true for the recent restitution of a whip and a bible from the holdings of the Linden-Museum Stuttgart to Namibia. ${ }^{83}$ The museum received these items as a gift from a colonial official in 1902. Originally, bible and whip had belonged to Hendrik Witbooi, a Nama leader who fought against the Germans and who is counted among the national heroes of Namibia. In February 2019, his belongings were transferred in a solemn official state ceremony that conveyed a powerful impression of the cultural importance of such objects for the deprived communities and, indeed, the potential to initiate the new relational ethics that

79 Monika Grütters and Michelle Müntefering: Eine Lücke in unserem Gedächtnis, in: Frankfurter Allgemeine Zeitung, 15 December 2018, URL: https://www.bundesregierung.de/ breg-de/bundesregierung/staatsministerin-fuer-kultur-und-medien/eine-luecke-in-unserem-ge daechtnis-1561942 (30 May 2019),

80 Deutscher Museumsbund: Leitfaden zum Umgang mit Sammlungsgut aus kolonialen Kontexten. 2. Fassung, Berlin 2019.

81 Ibid., 6.

82 See e.g. the contributions in Museumskunde 81/2016, vol. 1, Positioning Ethnological Museums in the $21^{\text {st }}$ century.

83 See Reinhart Kössler: The Bible and the Whip - Entanglements around the Restitution of robbed Heirlooms. ABI Working Paper No. 12, Freiburg 2019, URL: https://www.arnold-berg straesser.de/sites/default/files/field/pub-download/kossler_the_bible_the_whip_final_0.pdf (30 May 2019). Thomas Thiemeyer and Jochen von Bernstorff: Südwestdeutsch trifft DeutschSüdwest. Baden-Württemberg gibt zwei kolonialzeitliche Objekte an Namibia zurück, in: Merkur 840 (2019), 17-29. 
Sarr and Savoy invoke. At the same time, this restitution was accompanied by severe frictions between subnational groups and the Namibian state, who both laid claim to ownership and disposal of the restituted items, thereby exposing, as Reinhart Kössler has argued, that restitution can not only not undo colonialism and its consequences, it can even cause old colonial frictions to "become re-articulated in fresh conflicts on the ground." 84 The initiative to restitute whip and bible antedated the Macron moment by a few years, originating in negotiations between the Namibian Embassy and the owning state of BadenWürttemberg that started in 2013. Like the proactive move by the Amsterdam Rijksmuseum, this restitution must also be seen as a form of strategic cultural diplomacy by both the museum and the government of Baden-Württemberg as the legal owner of the museum collections. The Linden-Museum, already a pioneer of provenance research among Germany's ethnographic museums, ${ }^{85}$ established itself among the institutions working proactively for restitution. The Green government of Baden-Württemberg accrued the symbolic capital of a progressive leader in the moral politics of coming to terms with the country's colonial legacy, in contrast to the hesitant stand of the Grand Coalition in the federal government in Berlin.

The list of examples and reactions across the German political, academic, museal and cultural landscape could be extended, e.g. by an important memorandum drawn up by a consortium of ministers and politicians responsible for cultural affairs on the federal, state and communal level in March $2019 .{ }^{86}$

84 Kössler, The Bible and the Whip, 1.

85 See Gesa Grimme: Annäherungen an ein "Schwieriges Erbe". Provenienzforschung im Linden-Museum Stuttgart, in: Larissa Förster et al. (Hg.): Provenienzforschung zu ethnografischen Sammlungen der Kolonialzeit. Positionen in der aktuellen Debatte. Berlin 2017, 157-170 (http:// edoc.hu-berlin.de/18452/19800); Claudia Andratschke: Provenienzforschung in ethnographischen Sammlungen, in: Alexis von Poser and Bianca Baumann (eds): Heikles Erbe: Koloniale Spuren bis in die Gegenwart. Dresden 2016, 304-309.

86 The consortium defined the appropriate dealing with colonial collections as a central aspect of cultural policies and an important contribution to a shared postcolonial cultural memory. Apart from a pledge to transparency, accessibility and digitalization, the memorandum once more entrenched provenance research as the German approach to the problem, declaring it the indispensable basis for "determining the provenance and the circumstances of acquisition" of questionable objects: see Erste Eckpunkte zum Umgang mit Sammlungsgut aus kolonialen Kontexten der Staatsministerin des Bundes für Kultur und Medien, der Staatsministerin im Auswärtigen Amt für internationale Kulturpolitik, der Kulturministerinnen und Kulturminister der Länder und der kommunalen Spitzenverbände (13 March 2019), URL: https://www.kmk.org/ aktuelles/artikelansicht/eckpunkte-zum-umgang-mit-sammlungsgut-aus-kolonialen-kontexten. html (20 May 2019). 
This shows that the restitution debate is ongoing and liable to sudden changes. Still, there are three aspects that stand out as distinctive in Germany's take on displaced cultural heritage. First, and contrary to Sarr and Savoy's proposal, most decision-makers in German museum and cultural policies do not follow the report's automatism of colonial context leading to restitution. Rather, they take colonial contexts as an automatism that necessitates sensitive handling and thorough research. This procedure tries to do justice to historical accuracy and individual objects but remains unsatisfactory from the perspective of those who were historically deprived of their cultural heritage. They are, despite all pledges to dialogue, once more reduced to supplicants who are told to wait and play by the rules set by the privileged inheritors of an asymmetrical history, as Sarr and Savoy put it. This said, the report's emphasis on restitution has created media-fanned expectations of immediate action that has made the research on provenances already underway seem dilatory rather than progressive. Therefore, it should be particularly emphasized that those German museums that hold ethnographic collections have adopted a clear stand on the restitution of objects acquired under unjust conditions in their recent Heidelberg Declaration in May 2019. And while thorough provenance research takes time and thus tends to postpone restitution, it is a cooperative effort. Wherever it is practiced, it brings German institutions and curators into conversation with institutions, communities and individuals from the "source" regions. Thus, provenance research already puts into practice the new relational ethic demanded by the report.

Second, if regulating the problem through the highest authority of the state stands in the continuity of French centralism, the same is true for the federal approach that becomes visible in the varying German ways of addressing the legacies of the colonial past. The politics of culture and museums are predominantly federal affairs. The need to coordinate a far greater number of federal and communal actors and institutions than in the case of France or the Netherlands takes time and opens manoeuvring space for the self-positioning of individual states and museums. While some museums remain silent and hope to be overlooked until the storm might calm again, like it did so many times before, individual states, like Bremen or Hamburg, or museums, as in Hannover or Stuttgart, take the lead and accrue the symbolic capital of a progressive stand towards restitution and the confrontation with the colonial past. In doing so, they forge new networks with source communities, make themselves attractive for externallyfunded provenance research, exert pressure on institutions in a similar situation, and try to wield influence in the overall debate about displaced cultural heritage. The regional and municipal competition that is becoming visible today is an interesting equivalent of the "worldly provincialism" that drove museums (and the 
proud urban bourgeoisie supporting them) into an intra-German municipal competition for the biggest and most significant ethnographic collections. ${ }^{87}$

The third characteristic peculiarity of the German debates is their framing first and foremost in categories and institutions developed with a view to identify art looted during the Nazi regime. For example, in January 2019 the funding of colonial provenance research was entrusted to the German Lost Art Foundation (one of the members of the funding committee being Bénédicte Savoy), ${ }^{88}$ an institution for the restitution of displaced cultural property that traces its history back to the early 1990s. Established formally as a foundation in 2015, its main task consisted of facilitating the restitution of Jewish property confiscated under the Nazi regime, with an ever greater emphasis on formalized provenance research. Before taking up the funding of research into colonial provenances, the Foundation was also entrusted with research into the confiscation of cultural assets in the former GDR or the Soviet Occupation Zone. The path dependency of doing colonial provenance research using the terms and infrastructure of Nazi-related provenance research reflects the historical course of German expansionism but also the established way for German politics and society to come to terms with a problematic past. It makes good sense to draw upon existing databases and the already accumulated knowledge of art dealers and art markets. The treatment of colonial rule as another historical "context of injustice" alongside acknowledged dictatorial regimes also has the potential to weaken the principle of intertemporality and to enable, as in the case of Nazi Germany, the retrospective application of law. Undeniably, the restoration of historical colonial victimhood benefits from a coeval moral standing alongside acknowledged crimes against humanity. Yet, it remains a challenge to adequately reflect both contextual similarities and differences between centuries of asymmetric cultural encounter with their conjunctures of violence and racism and the systematic deprivation of existing rights, persecution and annihilation practiced under National Socialism.

\section{Conclusions}

Did the Sarr-Savoy report effect a "sea change" in the relationship between global North and global South, taking the debate on displaced cultural objects

87 Penny and Bunzl (eds.), Worldly Provincialism.

88 So far, however, its guidelines for application have not provided a mechanism, e.g., for scholars or source communities from the Global South to have the provenance of certain collections investigated. 
to new levels, as Jörg Häntzschel would have it? As yet, there has been much discussion and many ideas: we witness a museum world in motion and the forging of many new and promising networks between Western museums and source societies. Still, there has been far greater movement in discourse than of actual objects. In the light of decades of ebbs and flows in the international debate about displaced heritage, it remains to be seen whether we are currently experiencing just one more conjuncture, as in the early and late 1970s, or, indeed, the beginning of an "age of restitution" (Ciraj Rassool) or a "restitution revolution” (Bénédicte Savoy).

While a revolution may or may not be under way, the Sarr/Savoy-report has definitely shifted the moral parameters of debate. As a document consciously placed in the political arena, it contains elements similar to strategic litigation. Whatever Macron will decide, the report has established once more that the restitution of objects acquired under unjust conditions is the necessary and right thing to do. By privileging restitution over provenance research the report elevated those who supported immediate restitution to the moral high ground. Those arguing for historical complexity or those who deemed provenance research and cooperation with source communities the cutting edge of progressive work in museums, could suddenly find themselves on the wrong side of the moral equation. Doing or defending provenance research can seem like playing for time and an almost neo-colonial perpetuation of an untenable, unjust status quo. This said, the report also forces European audiences to approach the problem of displaced cultural heritage from a first and foremost African perspective. For those deprived of core objects of their cultural identity, any further deferral is, indeed, the perpetuation of historical injustice. However, the "African" perspective, as currently represented in European debates, so far consists mainly of contributions by public intellectuals like Felwine Sarr or Achille Mbembe, who have access to Western academia and publishing outlets. Other voices from "Africa” or indigenous communities are not missing, but they remain woefully underrepresented, despite the best efforts by journalists to dig up relevant voices and new perspectives ${ }^{89}$ or by the organizers of panel discussions to feature experts from Africa or at least with an African background. Tight budgets, language requirements and the multiplicity of possible source communities all combine to make the aim of coeval representation of African voices in European debates a challenging and partially random affair. Here, it would help if museums made their existing cooperations with source

89 See e.g. Jörg Häntzschel: Der Geist eines Kontinents, in: Süddeutsche Zeitung, 24 April 2019, URL: https://projekte.sueddeutsche.de/artikel/kultur/raubkunst-der-geist-eines-konti nents-e890780/?reduced=true (20 May 2019). 
communities more transparent and converted the silent expert knowledge of these partners at least partially into publicly audible voices.

For a historian whose academic socialization took place in the late 1990s and early 2000s, many of the arguments of the Sarr/Savoy-report read like a blast from the past of the late 1970s. My generation has been trained to question claims to fixed identities and think that nations are constructed, imagined communities created by elites who dexterously invent traditions and manipulate historical myths. Progressive historiography, as I have learned to understand it, is about transcending narrow containers of identity and a postcolonial approach to colonial history is about overcoming the inherited and powerful binary oppositions of black and white, colonizers and colonized, modern and traditional, centre and periphery, victims and perpetrators. For all the asymmetries and racism of the colonial encounter, the colonial situation was marked by subversion, mimicry, sly deception and the agency of the colonized, who limited the grand designs and all-powerful fantasies of the colonizers in decisive ways. Orientalist binaries were to be deconstructed, hybridity was the concept of the day. Sarr and Savoy, however, argue for cultural nation-building and cultural sovereignty as progressive instruments for African cultural decolonization when they present the "return of emblematic objects" as essential for the "construction of a political community" and the "reconstruction of the identity of subjects and communities". 90 Such essentialism may in part be strategic, but one is left to wonder how the political postcolonialism of restitution, with its emphasis on historical victimhood and future-oriented identitybuilding, can be reconciled with the epistemological postcolonialism practiced by Western academia during the last quarter of the century. It seems that practical agency in the present based upon a position of victimhood is preferred by many to a merely discursive agency in the past generously granted by Western historians.

In their relative disinterest for provenance, Sarr and Savoy privilege the African reclamation of history through the objects over the epistemological status of the objects as documents for an entangled history between Europe and Africa in the past. The future epistemologies of the objects are to be decidedly African, not so much entangled, and certainly not European. One is left to wonder, however, if it is entirely unavoidable or necessary to privilege restitution over provenance, to set ethics against law and history, and to play the future off against the past and Africa against Europe.

90 Sarr/Savoy: Restitution of African Cultural Heritage, 35. For an analytical notion of cultural sovereignty see Gregor Feindt, Bernhard Gissibl, Johannes Paulmann (eds.): Kulturelle Souveränität. Politische Deutungs- und Handlungsmacht jenseits des Staates im 20. Jahrhundert. Göttingen 2017, esp. 40-44, 227-283. 
Perhaps it would already help to unpack such loaded and homogenizing terms like "looted art" or "heritage" so as to differentiate the plurality of things lumped together in these categories. Thereby options could be recovered that are more flexible than the automatism of colonial context/restitution. The majority of objects are not art but material culture of everyday life. While they may still have significance for African societies, they are less likely to qualify as relevant heritage than, for example, ritual objects. The appropriate questions concerning such objects are not only about the circumstances of their acquisition but why and for what purposes they should remain hidden away in the storage rooms of European museums. Other objects are so obviously looted that there is simply no need for in-depth provenance research. The restitution of human remains has become an acknowledged ethical norm, although the practice of identification and return remains severely wanting. In such cases, museums should achieve the legal capacity to restitute, especially if one wants to avoid state actors using restitution as a tool for cultural diplomacy. Claimants, on the other hand, ought to be put in a legal position that ensures that the return of objects is more than a mere supplication granted by museums. It must evolve into an entitlement to be claimed, and return should also be a viable option for objects of cultural significance whose historical acquisition has been legitimate. There are fascinating suggestions in the debate about how to deal flexibly with objects that, for one reason or another, cannot yet be returned, such as immediately restoring ownership and then loaning them back until the best suited future place for these objects is negotiated. ${ }^{91}$ This is, indeed, the fourth dimension of the introspection Bénédicte Savoy demanded in her lecture at the Collège de France. Introspection, she wrote, must entail dreaming, the conjuring up of creative solutions for the future of cultural heritage, unprecedented legal constructions, new forms of partnership, flexible models adapted to the realities of different regions. ${ }^{92}$

There is one final and Eurocentric argument why it seems necessary that provenance research is not replaced by swift restitution, the entangled past of colonial objects not entirely eclipsed through their potential future after restitution. Historians Rebekka Habermas and Ulrike Lindner have pointed to the hitherto untold and unacknowledged histories of colonial artefacts and their constitutive role for the development of European arts and identities. ${ }^{93}$ Sarr and

\footnotetext{
91 This point has repeatedly been made by Jürgen Zimmerer, most recently in ZEIT Geschichte 4/19: Die Deutschen und ihre Kolonien. Hamburg 2019, 96.

92 Savoy: Provenienz der Kultur, 58.

93 Rebekka Habermas and Ulrike Lindner: Rückgabe - und mehr!, in: Die Zeit, 12 December 2018, URL: https://www.zeit.de/2018/52/kunst-kolonialzeit-rueckgabe-restitution-geschicht spolitik (30 May 2019).
} 
Savoy have argued that being in the presence and spell of these objects should no longer be reserved to the beneficiaries of privilege and asymmetrical mobility. The inconvenient truth is that European societies have made far too little of this privilege during the last century. Indeed, while some egregious pieces have been elevated to the status of art, the vast majority of objects has hardly ever been systematically dealt with. Museum curators have been hopelessly unable to cope with the sheer amount of objects, the majority of which had been stored away in magazines for decades. Not only do we know far too little about their concrete provenance but also about their histories and changing epistemologies after they were integrated into European collections. Not only African societies have a displaced heritage to rediscover. European publics, too, hardly know what riches have been acquired from faraway places, often bought and cared for with public money. The rediscovery of these objects in the current debate and an unprecedented transparency of museums about their collections is a unique opportunity for European societies to unlearn what these objects have told them about the colonized world in the past and to use them to learn about the deep involvement of their cities and societies in overseas colonialism. Indeed, every single object has the potential to teach European citizens about past colonial entanglements. Hence, Sarr and Savoy are to be credited for their report for yet another reason. Like no text, book, or statement before, the restitution report has thrown up the very real threat that European museums could really lose these objects whose presence has so long been taken for granted. We have finally started to attend to them. This opportunity should not be missed so that the acknowledgment of historical injustice can be based upon a profound and widespread societal knowledge of what colonialism was, in fact, about. 